\title{
Serum amyloid A protein (SAA) subtypes in acute and chronic inflammatory conditions
}

\author{
C P J MAURY, C EHNHOLM, AND M LUKKA
}

From the Fourth Department of Medicine, University of Helsinki and National Public Health Institute, Helsinki, Finland

SUMMARY Serum amyloid A (SAA), a polymorphic high density lipoprotein associated plasma protein, is the putative circulating precursor of tissue AA protein fibrils in reactive (secondary) amyloidosis. In the present study we examined the SAA subtype pattern in various acute and chronic inflammatory states in order to find out whether disease-specific SAA isoform profiles exist. The method used to study the subtype pattern is based on electrofocusing of serum followed by immunoblotting. Our results show that the SAA subtype pattern is similar in patients with rheumatoid arthritis with or without amyloid. In addition, in amyloidotic subjects the SAA subtype response to acute tissue injury (arthroplasty) did not differ from that in patients without amyloidosis. Analysis of patients with acute and chronic infectious diseases and non-rheumatic inflammatory conditions showed similar SAA patterns in all subjects. These results suggest that the SAA subtype response to tissue injury and inflammation is similar irrespective of the initiating stimulus.

Key words: isoforms, amyloidosis.

In reactive (secondary) amyloidosis the major constituent of the protein fibrils accumulating in various tissues is an $8.5 \mathrm{kD}$ polypeptide designated protein AA. This protein shows amino acid sequence homology with the $\mathrm{NH}_{2}$ portion of the $12 \mathrm{kD}$ serum amyloid $A$ protein, $S A A .^{1}$ In the circulation SAA is associated with high density lipoproteins (HDL) ${ }^{2} 3$ and shows characteristics of a sensitive acute phase reactant. ${ }^{14}$

Recent studies have shown the heterogeneity of SAA in several mammalian species. In humans six forms of SAA have been identified. ${ }^{356}$ It is not clear whether amyloid-specific or tissue-specific subtypes of SAA exist. In a recent study of a murine model of reactive amyloidosis Hoffman et al. ${ }^{7}$ showed that the AA protein deposited in tissues shared $\mathrm{NH}_{2}$ terminal amino acid sequence with only one of the two SAA isotypes found in murine plasma. In familial amyloidotic polyneuropathy it has been shown that a variant prealbumin represents

Accepted for publication 27 March 1985.

Correspondence to Dr C P J Maury. Assistant Professor of Medicine. Fourth Department of Medicine. Helsinki University Central Hospital, Unioninkatu 38. SF-00170 Helsinki, Finland. the biochemical cause of the disease and that this mutated protein deposits in tissues as amyloid. ${ }^{89}$ The purpose of the present study was to examine the SAA subtype pattern in various inflammatory conditions. In particular, the question of whether patients with amyloidosis have an altered SAA subtype profile was evaluated.

\section{Patients and methods}

PATIENTS

Reactive systemic amyloidosis

This group consisted of 10 patients, (seven female, three male, mean age 45 years, range $30-68$ years) with biopsy-proved amyloidosis. They all had rheumatoid arthritis as underlying disease. In these patients the concentration of SAA ranged from 58 to $146 \mathrm{mg} / \mathrm{l}$.

\section{Rheumatoid arthritis}

This group consisted of 10 patients (six female, four male, mean age 54 years, range 35-76 years) with no clinical signs of amyloidosis. Their concentration of SAA ranged from 93 to $405 \mathrm{mg} / \mathrm{l}$. 
Other diseases

This group consisted of two patients with juvenile rheumatoid arthritis (SAA 375 and $575 \mathrm{mg} / \mathrm{l}$ respectively), two patients with leprosy (SAA 42 and 55 $\mathrm{mg} / \mathrm{l}$ respectively), one patient with bacterial sepsis (SAA $900 \mathrm{mg} / \mathrm{l}$ ), one patient with glomerulonephritis (SAA $75 \mathrm{mg} / \mathrm{l}$ ), and one patient with intracerebral and subdural bleeding (SAA approximately 800 $\mathrm{mg} / \mathrm{l})$.

Studies during the acute phase reaction

These studies were carried out in two patients with reactive systemic amyloidosis undergoing arthroplasty, one patient with rheumatoid arthritis without amyloidosis undergoing arthroplasty, one renal transplant recipient having an acute allograft rejection, ${ }^{10}$ one liver transplant recipient having acute graft rejection, ${ }^{11}$ and one subject receiving injections of leucocyte interferon. ${ }^{12}$

\section{Effect of enzyme inhibitors}

To exclude the possible effect of proteolytic enzymes in serum on the SAA subtype pattern serum samples from a patient with rheumatoid arthritis were drawn into tubes containing aprotinin (Apronin) and trypsin inhibitor (Sigma, St Louis, Missouri, USA) and into control tubes without enzyme inhibitors.

\section{ELECTROFOCUSING}

\section{Pretreatment of sample}

$5 \mu \mathrm{l}$ serum sample was incubated for one hour at room temperature with $50 \mu \mathrm{l}$ of $10 \mathrm{mM}$ trometamol hydrochloride (TRIS-HCl) $\mathrm{pH} 8.2$ containing $1 \%$ decyl sulphate (w/v), 1\% ampholyte (LKB Ampholine $4-6(w / v)), 20 \%$ sucrose (w/v), and $10 \%$ 2-mercaptoethanol (v/v).

\section{Isoelectric focusing}

The focusing gel was prepared as follows: $2 \mathrm{~g}$ acrylamine (Bio-Rad) and $45 \mathrm{~g} N, N^{\prime}$-methylenebis(acrylamide) (Kodak) were dissolved and the volume adjusted to $40 \mathrm{ml}$ with deionized $8 \mathrm{M}$ urea. To this $1.2 \mathrm{ml}$ of Ampholine $\mathrm{pH}$ 4-6 (LKB) and $0.8 \mathrm{ml}$ of Ampholine $\mathrm{pH} 3.5-10$ (LKB) were added, and the solution was deaerated under reduced pressure. $75 \mu \mathrm{l} N, N, N^{\prime}, N^{\prime}$-tetramethylenediamine and $2 \mathrm{ml}$ of fresh $1 \%$ ammonium persulphate solution were added. Glasses, $1.5 \mathrm{~mm}$ spacers, and 10 well combs of the LKB 2001 vertical electrophoresis unit were used. $50 \mu \mathrm{l}$ aliquots of sample were used. The slots were filled with a solution containing $25 \mu$ l LKB Ampholine $\mathrm{pH} 4-6$ per $\mathrm{ml}$ and $7 \cdot 5 \%$ sucrose. The gel was focused for 16 hours at $250 \mathrm{~V}$ in an LKB 2001 vertical electrophoresis apparatus at $4^{\circ} \mathrm{C} .0 \cdot 2 \%$ sulphuric acid was used as anodal buffer and $0 \cdot 4 \%$ ethylenediamine as cathodal buffer.

\section{M M U NOB L O T T I N G}

After isoelectric focusing the gel to be blotted was washed briefly in distilled water and put on a glas plate. A Bio-Rad nitrocellulose membrane she was wetted in water and laid on the gel to make a airtight seal. Two pieces of filter paper and a layes of cellulose wad $1 \mathrm{~cm}$ thick were put on top of the membrane. The pocket was then evenly pressed fợ $1 \mathrm{~h}$ under another glass plate and a weight of $1 \mathrm{~kg}_{\vec{g}}$ After transfer the nitrocellulose paper was inf mersed for six hours in $10 \mathrm{mM}$ TRIS, $0.9 \%$ sodium chloride buffer $\mathrm{pH} 7.4$ (TBS) containing 3\% gelatio (Bio-Rad EIA grade). The membrane was the incubated overnight with rabbit anti-SAA, dilute

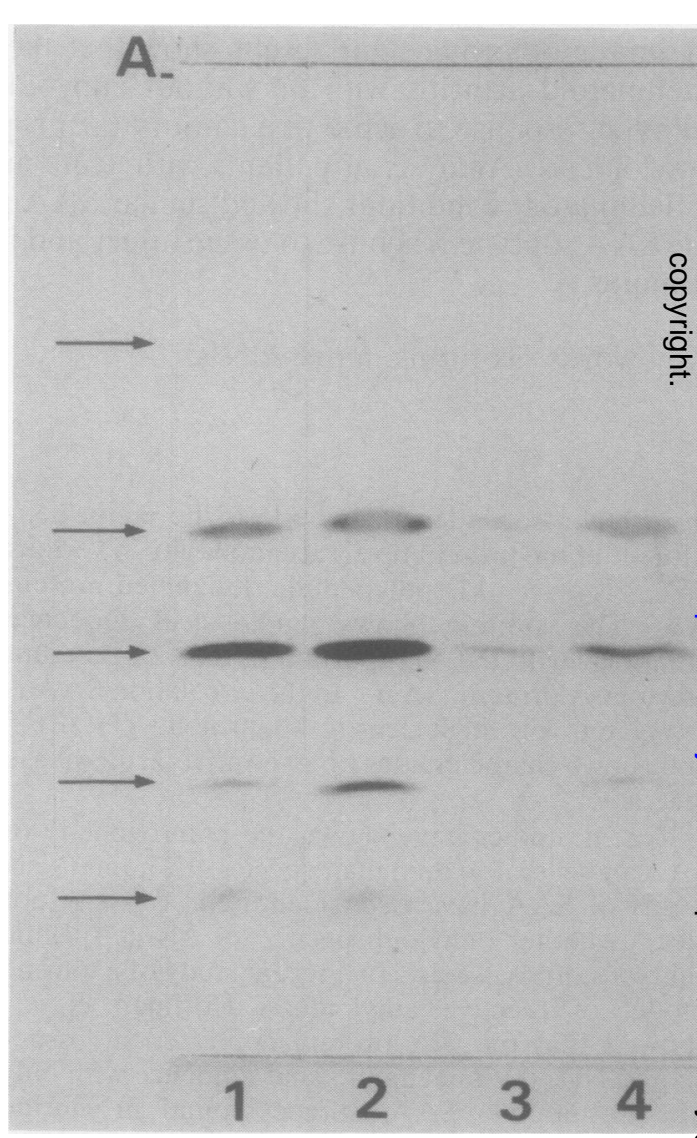

Fig. 1. SAA subtype patterns in acute inflammatory conditions. $A=$ application line. The arrows show the positions of the five $S A A$ isomers: $1=$ reference $S A A$ purified from $H D L ; 2=$ serum samples from patients with intracerebral and subdural bleeding; $3=$ active rheumatoid arthritis; and $4=$ bacterial sepsis. 
$1: 50$ in $1 \%$ gelatin-TBS. After incubation the membrane was washed for 40 minutes in TBS containing $25 \mu \mathrm{l}$ Tween 20 (Bio-Rad EIA grade) in $100 \mathrm{ml}$ TBS. The washed membrane was then incubated with affinity purified goat antirabbit IgG horseradish peroxidase (HRP) conjugated second antibody (Bio-Rad) in a dilution of $1: 2000$ in $1 \%$ gelatin-TBS for two hours and then washed as earlier. Finally, the membrane was immersed in colour developing solution: $60 \mathrm{mg}$ HRP colour development reagent (Bio-Rad) in $20 \mathrm{ml}$ cold $\left(-20^{\circ} \mathrm{C}\right)$ methanol, $100 \mathrm{ml} \mathrm{TBS}$, and $60 \mu \mathrm{l}$ of $30 \%$ hydrogen peroxide.

\section{A NTISERUM TO SAA}

SAA was purified from the plasma of a patient with glomerulonephritis caused by glomerular basement membrane antibodies, ${ }^{13}$ and antiserum was raised in rabbits as described elsewhere. ${ }^{13}$

IMMUNOCHEMICAL QUANTIFICATION OF S A A

Radial immunodiffusion was used to measure SAA. ${ }^{10}$

PLASMA LIPOPROTEIN ISOLATION

Plasma was obtained after an overnight fast, and the lipoproteins were isolated by sequential ultracentrifugation with $\mathrm{KBr}$ to adjust the density. ${ }^{14}$

\section{Results}

Two major and three minor isoforms of SAA could be shown with the present method (Fig. 1). Monitoring of the two major isoforms was possible in serum samples with moderately raised SAA levels, whereas monitoring of all five isoforms was possible only in samples containing more than $900 \mathrm{mg}$ of $\mathrm{SAA} / \mathrm{l}$. No difference in the SAA subtype pattern was observed between serum samples obtained with or without protease inhibitors (Fig. 2), suggesting that the SAA subtypes were not the result of the action of proteolytic serum enzymes after the withdrawal of the sample.

In order to study whether the SAA subtypes distributed evenly between the lipoproteins and the lipoprotein-free plasma fraction plasma was subjected to ultracentrifugal fractionation. As is evident from Fig. 2 SAA could be shown in the HDL and in the lipoprotein free infranatant fraction. No difference in the subtype distribution was observed.

Fig. 3 shows the SAA subtype profiles in patients with reactive systemic amyloidosis and patients with rheumatoid arthritis without amyloidosis. Similar subtype patterns were seen in both patient groups. The SAA pattern was also unaltered during acute phase reactions induced by surgery in amyloidotic and non-amyloidotic subjects (Fig. 2), during acute renal and liver allograft rejections (Fig. 3), and during interferon administration. The SAA subtype

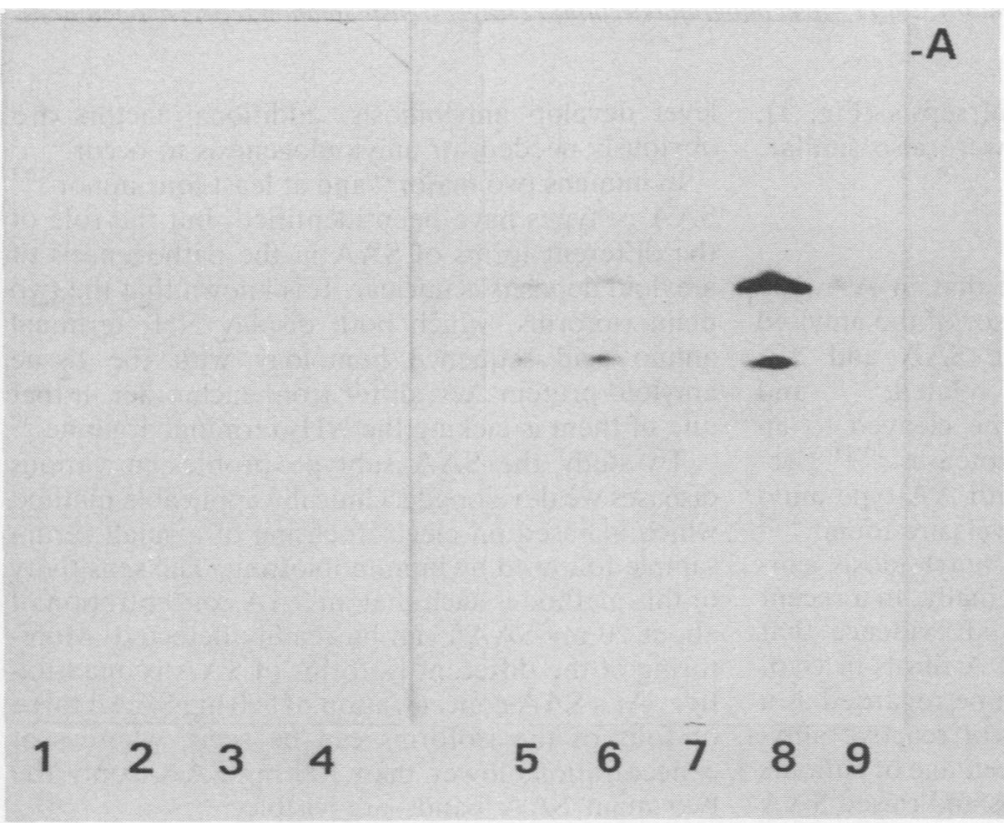

Fig. 2. SAA subtypes in lipoprotein fractions and lipoprotein-free plasma and the effect of enzyme inhibitors and surgery on the SAA subtype pattern. $I=$ lipoprotein-free infranatant fraction; $2=H D L$; $3=L D L$ (no $S A A$ bands visualised; $4=V L D L$ (no $S A A$ bands visualised); $5=$ fresh serum sample without inhibitors; $6=$ fresh serum sample + protease inhibitors; 7-9=arthroplasty. 


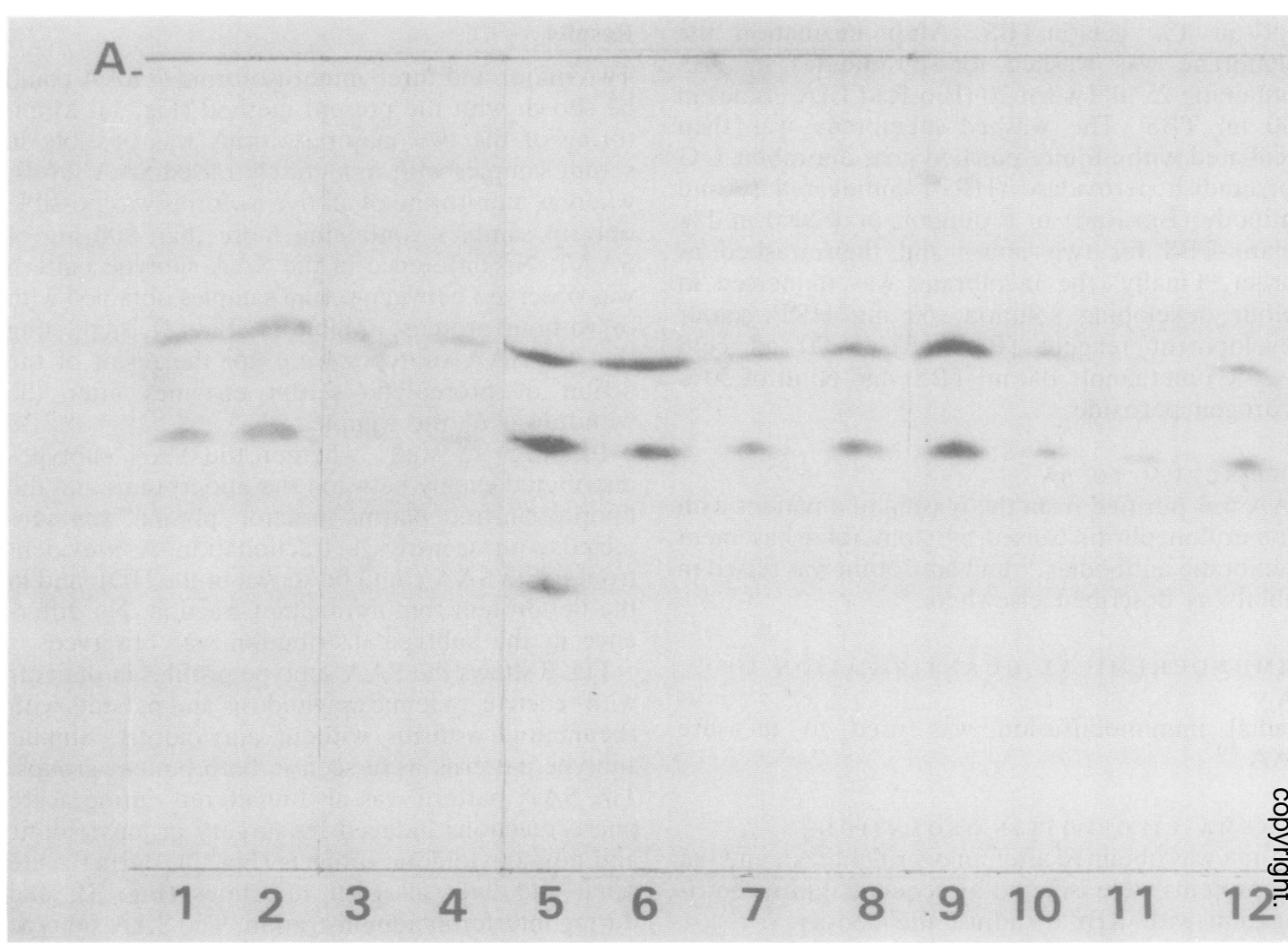

Fig. 3. SAA subtype patterns in patients with and without reactive amyloidosis. $1,2=$ rheumatoid arthritis; 3 . $4=$ rheumatoid arthritis + amyloidosis; $5=$ reference $S A A ; 6,7=$ juvenile rheumatoid arthritis; $8=$ renal allograft rejection 8 $9=$ renal transplantation (effect of operation); $10,11=$ liver allograft rejection; $12=$ liver transplantation (effect at operation) $\overline{\overline{0}}$

patterns in patients with bacterial sepsis (Fig. 1), leprosy, and glomerulonephritis were also similar.

\section{Discussion}

Several lines of evidence suggest that in AA-type amyloidosis the circulating precursor of the amyloid fibril protein is SAA. First, the SAA and AA proteins are structurally closely related, ${ }^{15-19}$ and SAA purified from plasma can be cleaved to an AA-sized fragment by serine proteases. ${ }^{20} 21 \mathrm{Sec}$ ondly, in conditions associated with AA-type amyloidois persistently raised SAA levels are found, ${ }^{4} 22$ and thirdly, the progression of amyloidosis correlates with raised SAA levels. ${ }^{23}$ Finally, in a recent report Husebekk et al. ${ }^{24}$ presented evidence that SAA can be deposited as amyloid A fibrils in vivo. At present a raised SAA level can be regarded as a prerequisite for the development of reactive amyloidosis, but since only a small percentage of patients with chronic inflammatory diseases and raised SAA level develop amyloidosis, additional factors are obviously needed for amyloidogenesis to occur. ${ }^{25}$ In humans two major ${ }^{26}$ and at least four minor ${ }^{5} 13$ SAA isotypes have been identified, but the role of the different forms of SAA in the pathogenesis of amyloid deposits is unclear. It is known that the two main isoforms, which both display $\mathrm{NH}_{2}$ terminal amino acid sequence homology with the tissue amyloid protein AA, differ from each other in thats one of them is lacking the $\mathrm{NH}_{2}$ terminal arginine. $\stackrel{2 \mathrm{2}}{=}$

To study the SAA subtype profiles in various diseases we developed a clinically applicable method which is based on electrofocusing of a small serump sample followed by immunoblotting. The sensitivity of this method is such that an SAA concentration of about $20 \mathrm{mg} \mathrm{SAA} / \mathrm{l}$ can be readily detected. Monio toring of the different isoforms of SAA is quantita tive. At a SAA concentration of $500 \mathrm{mg} \mathrm{SAA} / \mathrm{l}$ three or four of the isoforms can be seen, whereas at concentrations lower than $100 \mathrm{mg} \mathrm{SAA} / \mathrm{l}$ only the्ष two main SAA bands are visible. 
Our results show that the SAA subtype pattern is similar in patients with rheumatoid arthritis with or without amyloidosis. Moreover, in amyloidotic subjects the SAA subtype response to arthroplasty did not differ from that of rheumatic patients without amyloidosis. Analysis of patients with various acute and chronic infectious diseases and non-rheumatic inflammatory conditions showed similar SAA subtype patterns in all subjects, suggesting a nonspecific character of the SAA subtype response. These results are in conformity with those of previous studies in which SAA was first isolated by preparative ultracentrifugation and then subjected to ion exchange chromatography ${ }^{513}$ or electrofocusing. ${ }^{37}$ The present method of separating the SAA subtypes is based on charge differences of the molecular species. Therefore it should be pointed out that our finding of similar SAA subtype patterns in various diseases including reactive amyloidosis does not exclude the possible existence of amyloidspecific SAA molecules having differences in amino acid sequence but not different isoelectric points.

In conclusion, our results based on electrofocusing and immunoblotting do not show amyloidspecific SAA subtype patterns or any diseasespecific patterns, suggesting that the SAA subtype response to tissue injury and inflammation is similar irrespective of the initiating stimulus. With respect to amyloidogenesis our results suggest that though a persistently raised SAA level is a prerequisite for amyloid formation, other factors like tissue uptake mechanisms and degradation processes ${ }^{25}$ are likely to be important additional factors.

This study was supported by a grant from the Sigrid Juselius Foundation, Finland. Secretarial assistance from Ms Marita Heinonen is gratefully appreciated.

\section{References}

1 Glenner G G. Amyloid deposits and amyloidosis: the $\beta$ fibrilloses. $N$ Engl $J$ Med 1980; 302: 1283-92, 1333-42.

2 Benditt E P. Eriksen N. Amyloid protein SAA is associated with high density lipoprotein from human serum. Proc Natl Acad Sci USA 1977; 74: 4025-8.

3 Marhaug G, Sletten K. Husby G. Characterization of amyloid related protein SAA complexed with serum lipoproteins (apo SAA). Clin Exp Immunol 1982; 50: 382-9.

4 Maury C P J. Serum amyloid A protein - current status. Scand J Rheumatol 1984; 13: 97-100.

5 Bausserman L L, Herbert P N. McAdam K P W J. Heterogeneity of human serum amyloid A proteins. J Exp Med 1980; 152: $641-56$.

6 McAdam K P W J, Li J, Knowles J, et al. The biology of SAA: identification of the inducer, in vitro synthesis, and heterogeneity demonstrated with monoclonal antibodies. Ann NY Acad Sci 1982; 389: 126-36.

7 Hoffman J S. Ericsson L H. Eriksen N, Walsh K A, Benditt E P. Murine tissue amyloid protein $\mathrm{AA} \mathrm{NH}_{2}$-terminal sequence identity with only one of two serum amyloid protein (apoSAA) gene products. J Exp Med 1984; 159: 641-6.
8 Dwulet F E, Benson M D. Primary structure of an amyloid prealbumin and its plasma precursor in a heredofamilial polyneuropathy of Swedish origin. Proc Natl Acad Sci USA 1984: 81: 694-8.

9 Saraiva M J M, Birken S, Costa P P, Goodman D S. Amyloid fibril protein in familial amyloidotic polyneuropathy, Portuguese type. Definition of molecular abnormality in transthyretin (prealbumin). J Clin Invest 1984; 74: 104-19.

10 Maury C P J, Teppo A-M, Eklund B. Ahonen J. Serum amyloid A protein: a sensitive indicator of renal allograft rejection in humans. Transplantation 1983; 36: 501-4.

11 Maury C P J. Höckerstedt K. Teppo A-M, Lautenschlager I, Scheinin $T \mathbf{M}$. Changes in serum amyloid $A$ protein and microglobulin in association with liver allograft rejection. Transplantation 1984; 38: 551-3.

12 Maury C P J, Ehnholm C, Teppo A-M. Is interferon an inducer of serum amyloid A protein? $N$ Engl J Med 1983; 309: 1060-1.

13 Ehnholm C. Teppo A-M, Ohisalo J J, Maury C P J. Human high density lipoprotein associated amyloid A protein. Structural characteristics, relation to apo A-I and A-II concentrations and plasma clearance kinetics in the rat. Scand $J$ Rheumatol 1985; 14: 201-10.

14 Havel R J, Eder H A. Bragdon J H. Distribution and chemical composition of ultracentrifugally separated lipoproteins in human serum. J Clin Invest 1955; 34: 1345-53.

15 Levin M, Franklin E C, Frangione B. Pras M. The amino acid sequence of a major nonimmunoglobulin component of some amyloid fibrils. J Clin Invest 1972: 51: 2773-6.

16 Ein D, Kimura S, Terry W D, Magnotta J. Glenner G G. Amino acid sequence of an amyloid fibril of unknown origin. $J$ Biol Chem 1972; 247: 5653-5.

17 Anders R F, Natvig J B, Michaelsen T E, Husby G. Isolation and characterization of amyloid related serum protein $S A A$ as a low molecular weight protein. Scand J Immunol 1975; 4: 397-401.

18 Linke R P. Sipe J D. Pollock P S, Ignaczak T F. Glenner G G. Isolation of a low-molecular weight serum component antigenically related to an amyloid fibril protein of unknown origin. Proc Natl Acad Sci USA 1975; 72: 1473-6.

19 Parmelee D C. Titani K. Ericsson L H, Eriksen N, Benditt E P, Walsh K A. Amino acid sequence of amyloid-related apoprotein (apoSAA) from human high-density lipoprotein. Biochemistry 1982; 21: 3298-303.

20 Lavie G, Zucker-Franklin D, Franklin E C. Elastase-type proteases on the surface of human blood monocytes: possible role in amyloid formation. $J$ Immunol 1980; 125: 175-80.

21 Skogen B. Thorsteinsson L. Natvig J B. Degradation of protein SAA to an AA-like fragment by enzymes of monocytic origin. Scand J Immunol 1980; 11: 533-40.

22 deBeer F C, Hallga R K. Fagan B A, Lanham J G, Hughes R G V. Pepys M B. Serum amyloid A protein concentration in inflammatory diseases and its relationship to the incidence of reactive systemic amyloidosis. Lancet 1982; ii: 231-3.

23 Falck H M. Maury C P J. Teppo A-M, Wegelius O. Persistently high serum amyloid $\mathrm{A}$ protein and $\mathrm{C}$-reactive protein levels correlate with rapid progression of secondary amyloidosis. $\mathrm{Br} \mathrm{J}$ Med 1983; 286: 1391-4.

24 Husebekk A, Skogen B, Husby G, Marhaug G. Transformation of amyloid precursor SAA to protein AA and incorporation in amyloid fibrils in vivo. Scand J Immunol 1985; 21: 283-7.

25 Maury C P J, Teppo A-M. Mechanism of reduced amyloid-Adegrading activity in serum of patients with secondary amyloidosis. Lancet 1982; ii: 234-7.

26 Eriksen N, Benditt E P. Isolation and characterization of the amyloid-related apoprotein (SAA) from human high density lipoprotein. Proc Natl Acad Sci USA 1980; 77: 6860-4.

27 Eriksen N, Benditt E P. Trauma, high density lipoproteins, and serum amyloid protein A. Clin Chim Acta 1984; 140: 139-49. 